\title{
Effect of dietary betaine supplementation on the performance, carcass yield, and intestinal morphometrics of broilers submitted to heat stress
}

\section{-Author(s)}

Sakomura $\mathrm{NK}^{1 *}$

Barbosa NAA ${ }^{1}$

Longo $\mathrm{FA}^{2}$

Silva EP da²

Bonato $\mathrm{MA}^{1}$

Fernandes JBK

Department of Animal Science, School of Agricultural and Veterinary Sciences, Universidade Estadual Paulista Júlio de Mesquita Filho, Jaboticabal, São Paulo, Brazil.

2 Btech Brasil, São Paulo, Brazil.

Aquaculture Center, Universidade Estadual Paulista Júlio de Mesquita Filho, Jaboticabal São Paulo, Brazil.

\section{Mail Adress}

*Corresponding author e-mail address

E-mail: sakomura@fcav.unesp.br

\begin{abstract}
The objective of this study was to evaluate the effect of betaine in methionine- and choline-reduced diets fed to broilers submitted to heat stress. In total, 1,408 male broilers were randomly distributed into eight treatments, according to $2 \times 4$ (environment $x$ diet) factorial arrangement, with eight replicates of 2 birds each. Birds were reared environmental chambers under controlled temperature $\left(25-26{ }^{\circ} \mathrm{C}\right)$ or cyclic heat-stressing temperature $\left(25-31^{\circ} \mathrm{C}\right)$. The following diets were tested: positive control ( $\mathrm{PC}$ ), formulated to meet broiler nutritional requirements; negative control (NC), with reduced DL-methionine and choline chloride levels; and with two supplementation levels of natural betaine to the negative control diet $(\mathrm{NC}+\mathrm{NB} 1$ and $\mathrm{NC}+\mathrm{NB} 2)$. Live performance, carcass traits, and intestinal morphometrics were evaluated when broilers were 45 days of age. The results showed that all evaluated parameters were influenced by the interaction between environment and diet, except for breast meat drip loss. The breakdown of the interactions showed that birds fed the PC diet and reared in the controlled environment had greater breast drip loss than those submitted to the cyclic heat-stress environment. Birds submitted to cyclic heat stress and fed the PC diet presented the lowest feed intake. Feed conversion ratio was influenced only by diet. The FCR of broilers fed the NC+NB2 diet was intermediate relative to those fed the PC and NC diets. The addition of betaine in the diet, with $11.18 \%$ digestible methionine and $24.73 \%$ total choline reductions, did not affect broiler live performance, carcass yield, or intestinal morphometrics.
\end{abstract}

\section{INTRODUCTION}

Natural betaine is found in several plants and organisms (Botch et al., 1994), and it is commonly extracted and purified from beetroot. It is classified as a methyl-ammonia due to three chemically-active methyl groups bound to the nitrogen atom of a glycine molecule (Kidd et al., 1997), and it is considered the only readily active methyl-group donor (Kettunen et al., 2001).

The biosynthesis of betaine is made by the oxidation of choline in the cell mitochondrion. However, according to Kidd et al. (1997), this reaction is not interesting because choline deviated from its essential role in the transmission of nerve impulses, and in addition, choline content in typical corn- and soybean-based broiler diets is not sufficient supply their cell requirements for methylated compounds (Pesti et al., (1979). Another positive aspect obtained with the dietary inclusion of betaine is the methionine-saving effect, that is, betaine donates methyl groups instead of methionine in a reaction with homocysteine (Paniz et al., 2005). 
Betaine plays two main roles in metabolism: The first is to donate methyl radicals, and the second is related to its zwitterionic characteristic, that is, it is an osmolyte that helps maintaining cell water homeostasis (Klasing et al., 2002) without affecting cell metabolism.

As an osmolyte, betaine allows proteins to maintain their conformational stability in the presence of high uric acid concentrations and changes in cell salinity. Several tissues depend on betaine as an osmolyte, including the kidneys, brain, liver, intestines, and leukocytes (Klasing et al., 2002).

The osmoprotectant action of betaine ameliorates the effects of heat stress and of acid-base balance changes (Honarbakhsh et al., 2007) that may compromise physiological and metabolic functions, and consequently, broiler performance and feed efficiency (Honarbakhsh et al., 2007).

Betaine is reported to contribute to attenuate the detrimental effects of coccidiosis (Augustine et al., 1997), partially inhibiting coccidiosis development and improving intestinal structure and function.

This study aimed at evaluating the effects of the supplementation of betaine in the diet of broilers submitted to two different thermal environments on their performance, carcass traits, and intestinal morphology.

\section{MATERIALS AND METHODS}

The experiment was carried out in the environmental chamber of the Poultry Sector of the Department of Animal Science of the School of Agricultural and Veterinary Sciences of UNESP, Jaboticabal campus, SP, Brazil.
In this trial, 1,408 one-day-old male Cobb® broilers. Birds were individually weighed and grouped in weight ranges, according to Sakomura and Rostagno (2007).

Birds were distributed into eight treatments with eight replicates of 22 birds each. A completely randomized experimental design in a $2 \times 4$ factorial arrangement was applied, consisting of two thermal environments (cyclic heat stress $-25-31^{\circ} \mathrm{C}$; controlled temperature $-24-27^{\circ} \mathrm{C}$ ) and four diets.

During the starter phase (1-21 days of age), all birds were housed in four environmental chambers under thermoneutral conditions. From 22 days of age until the end of the trial, birds were submitted to the above described thermal environments in order to evaluate heat stress effects. Four environmental chambers were used for the two environments: Cyclic heat stress or controlled temperature. Cyclic heat stress conditions were based on the temperature changes to which broilers are commonly submitted when reared in commercial settings in the region: hot temperatures during the day and mild temperatures during the night. In order to simulate these conditions in the environmental chambers, brooders were used during the day, and air-conditioning to achieve thermoneutral temperatures during the night.

We used the following procedures for all environments, from 22 days of age: The controlled environment was obtained by keeping the chambers closes and the air conditioning on, providing an average temperature of $25^{\circ} \mathrm{C}$ during 24 hours per day.

In order to provide the cyclic heat stress environment to the birds, at 08:00h and 20:00h, after temperature and relative humidity were recorded, heaters or air-conditioning were turned

Table 1 - Mean maximum and minimum temperature $\left({ }^{\circ} \mathrm{C}\right)$ and air relative humidity (\%) recorded in the chambers in the periods of 1-21 and 22-45 days of age.

\begin{tabular}{|c|c|c|c|c|c|c|c|}
\hline \multirow{2}{*}{ Environment } & \multirow{2}{*}{ Period } & \multicolumn{3}{|c|}{ Temperauture } & \multicolumn{3}{|c|}{ Relative humidity } \\
\hline & & Cyclic heat stress & Minimum & Average & Maximum & Minimum & Average \\
\hline \multicolumn{8}{|c|}{ 1-21 days of age } \\
\hline Controlled & Day-noite & 32.53 & 27.98 & 30.59 & 60.01 & 39.19 & 49.21 \\
\hline \multicolumn{8}{|c|}{$22-45$ days of age } \\
\hline \multirow{2}{*}{ Heat stress } & Day & 32.9 & 25.3 & 29.1 & 62.8 & 42.9 & 52.9 \\
\hline & Night & 28.1 & 24.4 & 26.3 & 60.7 & 47.0 & 53.9 \\
\hline \multirow{2}{*}{ Controlled } & Day & 28.2 & 24.2 & 26.2 & 61.8 & 48.9 & 55.4 \\
\hline & Night & 26.1 & 23.7 & 24.9 & 61.7 & 52.5 & 57.6 \\
\hline
\end{tabular}

${ }^{1}$ Temperature treatments started when birds were 22 days of age 
off and the chambers were opened for 30 minutes in order to have the same internal and external temperatures. After this period, chambers were kept closed and heaters were turned on in the morning and air conditioners in the night.

Maximum and minimum temperature and air relative humidity were daily recorded using three digital thermo-hygrometers placed inside each environmental chamber. Measurements were made at 08:00, 11:00, 15:00, 20:00, and 23:00 hour during the grower and the finisher phase. The recorded values are presented in Table 1.

Birds started receiving the experimental diets with one day of age. Four diets were offered. The positive control diet (PC) was formulated to supply the nutritional requirements for each phase, and was supplemented with $0.368,0.328,0.318$, and $0.254 \%$ DL-methionine $99 \%$ and $0.062,0.062,0.062$, and $0.053 \%$ choline chloride $60 \%$ during the periods of 1 to 7,8 to 21,22 to 35 , and 35 to 42 days of age, respectively.

The negative control diet (NC) presented reduced DL-methionine 99\% supplementation levels and no choline chloride was added, as follows: DLmethionine was added at $0.102,0.107,0.066$, and $0.049 \%$, corresponding to $0.226,0.221,0.252$, and $0.254 \%$ for the periods of 1 to 7,8 to 21,22 to 35 , and 35 to 42 days of age, respectively. The formula with DL-methionine reduction and choline chloride withdrawal was adjusted by the addition of inert material.

Diet NC+NB1, corresponding to treatment 3, contained $0.092,0.096,0.065$, or $0.05 \%$ natural betaine in partial replacement of DL-methionine $99 \%$ and total choline chloride $60 \%$, and was fed during the periods of 1 to 7,8 to 21,22 to 35 , and 35 to 42 days of age, respectively

Diet NC+NB2, corresponding to treatment 4 (T4), contained $0.100,0.100,0.075$, or $0.075 \%$ natural betaine in partial replacement of DL-methionine 99\% and total choline chloride 60\%, and was fed during the periods of 1 to 7,8 to 21,22 to 35 , and 35 to 42 days of age, respectively. The formulas with natural betaine inclusion were adjusted by the withdrawal of inert material.

Feeds were based on corn and soybean meal, and formulated according to the recommendations of Rostagno et al. (2005), and were free from growth promoters and anticoccidials. The composition of the positive control diet and the calculated nutritional levels, per rearing phase, are presented in Table 2.
Table 2 - Ingredient composition and calculated nutritional levels of the experimental diets

\begin{tabular}{|c|c|c|c|c|}
\hline Ingredients & $\begin{array}{c}C P^{1} \\
1-7 \text { days }\end{array}$ & $\begin{array}{c}C P^{2} \\
8-21 \text { days }\end{array}$ & $\begin{array}{c}C P^{3} \\
22-35 \text { days }\end{array}$ & $\begin{array}{c}\mathrm{CP}^{3} \\
36-45 \text { days }\end{array}$ \\
\hline Corn & 52.366 & 57.039 & 59.998 & 58.741 \\
\hline Soybean meal 45\% & 39.66 & 34.491 & 29.501 & 27.799 \\
\hline Soybean oil & 3.253 & 3.932 & 5.997 & 7.279 \\
\hline Dicalcium phosphate & 1.853 & 1.832 & 1.87 & 2.16 \\
\hline Limestone & 0.958 & 0.907 & 0.974 & 0.932 \\
\hline Salt & 0.659 & 0.612 & 0.458 & 0.543 \\
\hline DL-Methionine 99\% & 0.368 & 0.328 & 0.318 & 0.254 \\
\hline L-lysine 78\% & 0.246 & 0.222 & 0.248 & 0.165 \\
\hline Vitamin supplement & 0.100 & 0.100 & 0.100 & 0.100 \\
\hline Choline chloride $60 \%$ & 0.062 & 0.062 & 0.062 & 0.053 \\
\hline Mineral supplement & 0.050 & 0.050 & 0.050 & 0.050 \\
\hline Betafin ${ }^{4}$ & 0.000 & 0.000 & 0.000 & 0.000 \\
\hline Inert material ${ }^{5}$ & 0.425 & 0.425 & 0.425 & 1.925 \\
\hline Total & 100 & 100 & 100 & 100 \\
\hline \multicolumn{5}{|l|}{ Calculated levels } \\
\hline Total choline, mg/kg & 1.700 & 1.600 & 1500 & 1400 \\
\hline AMEn, kcal/kg & 2.950 & 3.050 & 3218 & 3250 \\
\hline Crude protein, \% & 23 & 21 & 19 & 18 \\
\hline Digestible lysine, \% & 1.3 & 1.16 & 1.06 & 0.95 \\
\hline $\begin{array}{l}\text { Digestible methionine, } \\
\%\end{array}$ & 0.679 & 0.616 & 0.581 & 0.506 \\
\hline $\begin{array}{l}\text { Digestible } \\
\text { methionine+cystine, \% }\end{array}$ & 0.975 & 0.893 & 0.837 & 0.751 \\
\hline Calcium, \% & 0.97 & 0.93 & 0.95 & 1 \\
\hline Available phosphorus, \% & 0.46 & 0.45 & 0.45 & 0.499 \\
\hline Sodium, \% & 0.305 & 0.283 & 0.22 & 0.252 \\
\hline
\end{tabular}

\section{PC, positive control;}

${ }^{1}$ Vitamin supplement pre-starter (content per $\mathrm{kg}$ product, included per ton of feed): folic acid $1000 \mathrm{mg}$, pantothenic acid $15000 \mathrm{mg}$, antioxidant $0.5 \mathrm{~g}$, niacin $40000 \mathrm{mg}$, selenium 300 mg, biotin 60 mg, vit B1 1800 mg, vit B12 12000 mcg, vit B2 6000 mg, vit B6 2800 mg, vit D3 2000000 Ul, vit E 15000 mg, vit K3 1800 mg. Mineral supplement (content per $\mathrm{kg}$ product, added at $0.5 \mathrm{~kg} /$ ton of feed): manganese $150000 \mathrm{mg}$, zinc $100000 \mathrm{mg}$, iron $100000 \mathrm{mg}$, copper $16000 \mathrm{mg}$, iodine $1500 \mathrm{mg}$.

${ }^{2}$ Vitamin supplement starter (content per $\mathrm{kg}$ product, included per ton of feed): folic acid $1000 \mathrm{mg}$, pantothenic acid $15000 \mathrm{mg}$, antioxidant $0.5 \mathrm{~g}$, niacin $40000 \mathrm{mg}$, selenium300 mg, biotin 60 mg, vit B1 1800 mg, vit B12 12000 mcg, vit B2 6000 mg, vit B6 2800 mg, vit D3 2000000 Ul, vit E 15000 mg, vit K3 1800 mg. Mineral supplement (content per $\mathrm{kg}$ product, added at $0.5 \mathrm{~kg} / \mathrm{ton}$ of feed): manganese $150000 \mathrm{mg}$, zinc $100000 \mathrm{mg}$, iron $100000 \mathrm{mg}$, copper $16000 \mathrm{mg}$, iodine $1500 \mathrm{mg}$.

${ }^{3}$ Vitamin supplement grower (content per kg product, included per ton of feed, 22-45 days): folic acid $700 \mathrm{mg}$, pantothenic acid $13000 \mathrm{mg}$, antioxidant $0.5 \mathrm{~g}$, niacin 35000 mg, selenium 300 mg, vit B1 1600 mg, vit B12 10000 mcg, vit B2 5000 mg, vit B6 2600 mg, vit D3 1500000 UI, vit E 12000 mg, vit K3 1500 mg. Mineral supplement (content per $\mathrm{kg}$ product, added at $0.5 \mathrm{~kg} / \mathrm{ton}$ of feed): manganese $150000 \mathrm{mg}$, zinc $100000 \mathrm{mg}$, iron $100000 \mathrm{mg}$, copper $16000 \mathrm{mg}$, iodine $1500 \mathrm{mg}$

${ }^{4}$ Betafin $\mathrm{S} 1 \circledast$ (Danisco Animal Nutrition) with $96 \%$ de purity was used as natural betaine source;

${ }^{5}$ Washed sand was used as inert material;

${ }^{6}$ Calculation based on the concentrations in the ingredients presented in the NRC (1994) tables. 
Birds were vaccinated in the hatchery against Marek's disease and fowl pox, And on the third day against coccidiosis via drinking water. Drinkers were cleaned every other day to enhance health challenge.

The following performance parameters were evaluated: feed intake (g/bird), weight gain (g/bird), and feed conversion ratio $(\mathrm{g} / \mathrm{g})$. Feed conversion ratio was corrected for mortality, according to Sakomura and Rostagno (2007).

Carcass traits were evaluated at 45 days of age in two birds per experimental unit, which were selected based on the average weight. After $12 \mathrm{~h}$ of feed fasting, birds were weighed, stunned using carbon dioxide $\left(\mathrm{CO}_{2}\right)$, and bled. Carcasses were then scalded $\left(65^{\circ} \mathrm{C}\right)$, plucked, and eviscerated. Carcass yield corresponded to carcass weight without head, neck, or feet, relative to fasted live weight. Breast and leg (drumstick+thigh) were cut from the carcass and weighed, and their yield was expressed relative to carcass weight.

In order to determine parts drip loss, parts were placed in duly identified polyethylene bags, sealed at atmospheric pressure, and frozen for 48 hours at $-4^{\circ} \mathrm{C}$. After this time, parts were again weighed (Bridi et al., 2003). Drip loss was calculated as the difference between initial weight and final weight, and expressed as a percentage. Carcass drip loss was calculated as the drip loss of all carcass parts.

In order to assess intestinal morphology, one bird per experimental unit was sacrificed at 45 days of age after $12 \mathrm{~h}$ fasting for jejunum collection. Approximately $2 \mathrm{~cm}$ of the jejunum, between the distal portion of the duodenum loop and Meckel's diverticulum, were collected. This segment was longitudinal opened and immediately fixed in Bouin solution for 24 hours. Samples were then in alcohol at $70 \%$ to remove the fixing solution, dehydrated in graded alcohol series, cleared in xylol, and embedded in paraffin.

Semi-serial, 5- $\mu \mathrm{m}$ thick, tissue sections stained in hematoxylin and eosin were evaluated according to the methodology of Behmer et al. (1976). Slides were mounted with Canada Balm, and then photographed under a magnifying glass (LEICA DM 2500) at 5x magnification, with the aid of the software program LEICA QWin V3. The morphological analysis of the intestinal mucosa was performed under light microscopy using the software program Image $®$ (Rasband, 2004). Villus height and crypt depth were determined, with 30 readings per replicate/region.

Performance parameters were evaluated for the entire experimental period (1-45 days) because the effect was cumulative.
Results were submitted to analysis of variance using the GLM procedure of SAS (2001) statistical package and means were compared by the test of Tukey at $5 \%$ significance level.

\section{RESULTS AND DISCUSSION}

The performance results obtained for the period of 1-45 days of age (Table 3 ) indicate that bird responded differently when under heat stress. Broilers submitted to cyclic heat stress had lower feed intake.

Birds fed the negative control diet presented higher feed intake compared with those receiving the positive control feed. Feed intake response is related to nutrient deficiency rate in the diet: under small restrictions, birds increase their feed intake to try to obtain enough amounts of the limiting nutrients (Bowmaker\&Gous, 1991). When betaine was fed, broilers recovered their feed intake; however, birds were not sensitive to the different betaine levels. No significant interaction ( $p>$ 0.05 ) between diet and environment was detected, as shown in Table 3.

The effect of the environment on feed intake was reflected on weight gain, which was higher $(p<0.0001)$ in the broilers maintained in the controlled environment.

Feed conversion ratio was affected only by diet $(p<0.05)$. Considering feed conversion ratio in the PC group as $100 \%$, birds in groups NC, NC+NB1, and NC+NB2 increased in $+2.434,+1.730$, and $+1.281 \%$, respectively. The feed conversion ratio of broilers fed the diet with betaine supplementation was intermediate relative to those fed the positive and the negative control diets. The responses to betaine supplementation were expected to be more evident. Nevertheless, the NC+NB2 diet promoted better recovery of the feed conversion ratio than the positive control diet.

According to Hassan et al. (2005), the inclusion of betaine in broiler diets was more effective in improving their performance than choline. On the other hand, some studies did not find any significant results when methionine was completely or partially replaced by betaine (Rostagno \& Pack, 1996; Schutte et al., 1997).

It was expected that the dietary supplementation of betaine would influence carcass and parts weights (Table 4) due to its methyl-group donor property, which would increase methionine, cystine (McDevitt et al., 2000), and glycine for protein synthesis and also contribute to reduce fat deposition in the carcass 
Table 3 - Means and probability values (p) of the analysis of variance of feed intake ( $\mathrm{Fl}, \mathrm{kg})$, weight gain (WG, $\mathrm{kg} / \mathrm{bird})$, and feed conversion ratio $(F C R, \mathrm{~kg} / \mathrm{kg}$ ) of broilers fed the experimental diets and submitted to different environmental conditions during the period of 1-45 days of age.

\begin{tabular}{|c|c|c|c|c|c|c|c|c|}
\hline \multirow{2}{*}{ Item } & \multirow{2}{*}{ Diet (D) } & \multicolumn{2}{|c|}{ Environment (E) } & \multirow{2}{*}{ General } & \multicolumn{3}{|c|}{$P$ value } & \multirow{2}{*}{$\mathrm{CV}(\%)$} \\
\hline & & Heat stress & Controlled & & $\mathrm{D}$ & $E$ & $\mathrm{D} \times \mathrm{E}$ & \\
\hline \multirow{5}{*}{$\mathrm{FI}$} & PC & 4.263 & 4.716 & $4.489 \mathrm{C}$ & \multirow{5}{*}{ ** } & \multirow{5}{*}{ ** } & \multirow{5}{*}{ NS } & \multirow{5}{*}{3.25} \\
\hline & NC & 4.571 & 4.863 & $4.751 \mathrm{~A}$ & & & & \\
\hline & $\mathrm{NC}+\mathrm{NB} 1$ & 4.475 & 4.786 & $4.652 \mathrm{AB}$ & & & & \\
\hline & $\mathrm{NC}+\mathrm{NB} 2$ & 4.395 & 4.763 & 4.622 B & & & & \\
\hline & General & $4.414 b$ & $4.784 a$ & & & & & \\
\hline \multirow{5}{*}{ WG } & $P C$ & 2.725 & 3.030 & 2.877 & \multirow{5}{*}{ NS } & \multirow{5}{*}{$\star \star$} & \multirow{5}{*}{ NS } & \multirow{5}{*}{3.28} \\
\hline & NC & 2.828 & 3.062 & 2.972 & & & & \\
\hline & $\mathrm{NC}+\mathrm{NB} 1$ & 2.830 & 3.005 & 2.930 & & & & \\
\hline & $\mathrm{NC}+\mathrm{NB} 2$ & 2.817 & 2.988 & 2.922 & & & & \\
\hline & General & $2.795 b$ & $3.021 \mathrm{a}$ & & & & & \\
\hline \multirow{5}{*}{ FCR } & PC & 1.564 & 1.556 & $1.561 \mathrm{~A}$ & \multirow{5}{*}{ * } & \multirow{5}{*}{ NS } & \multirow{5}{*}{ NS } & \multirow{5}{*}{2.30} \\
\hline & NC & 1.618 & 1.588 & 1.599 B & & & & \\
\hline & $\mathrm{NC}+\mathrm{NB} 1$ & 1.582 & 1.593 & $1.588 \mathrm{AB}$ & & & & \\
\hline & $\mathrm{NC}+\mathrm{NB} 2$ & 1.560 & 1.594 & $1.581 \mathrm{AB}$ & & & & \\
\hline & General & 1.579 & 1.583 & & & & & \\
\hline
\end{tabular}

$\mathrm{PC}$, positive control; NC, negative control; NB1, natural betaine supplementation level 1; NB2, natural betaine supplementation level $2 ;{ }^{*} p<0.05$; ${ }^{* *} p<0.01$; NS, not significant; $C V$, coefficient of variation, \%

Means followed by the small letters in the same row and capital letters in the same column are not significantly different by the test of Tukey at $5 \%$ probability level.

Table 4 - Carcass, leg, and breast yields (\%) of 45-d-old broilers reared under different environmental conditions and fed diets supplemented or not with betaine.

\begin{tabular}{|c|c|c|c|c|c|c|c|c|}
\hline \multirow{2}{*}{ Item } & \multirow{2}{*}{$\operatorname{Diet}(D)$} & \multicolumn{2}{|c|}{ Environment (E) } & \multicolumn{4}{|c|}{ Probability } & \multirow{2}{*}{$C V$} \\
\hline & & Heat stress & Controlled & General & D & $E$ & $\mathrm{D} \times \mathrm{E}$ & \\
\hline \multirow{5}{*}{ Carcass } & PC & 72.24 & 72.65 & 72.45 & \multirow{5}{*}{ NS } & \multirow{5}{*}{ NS } & \multirow{5}{*}{ NS } & \multirow{5}{*}{2.24} \\
\hline & NC & 72.11 & 72.57 & 72.34 & & & & \\
\hline & $\mathrm{NC}+\mathrm{NB} 1$ & 71.73 & 72.36 & 72.05 & & & & \\
\hline & $\mathrm{NC}+\mathrm{NB} 2$ & 72.61 & 72.63 & 72.62 & & & & \\
\hline & General & 72.17 & 72.55 & & & & & \\
\hline \multirow{5}{*}{ Leg } & PC & 21.90 & 21.73 & 21.82 & \multirow{5}{*}{ NS } & \multirow{5}{*}{ NS } & \multirow{5}{*}{ NS } & \multirow{5}{*}{4.19} \\
\hline & NC & 21.84 & 21.87 & 21.86 & & & & \\
\hline & $\mathrm{NC}+\mathrm{NB} 1$ & 21.29 & 21.50 & 21.40 & & & & \\
\hline & $N C+N B 2$ & 22.19 & 21.85 & 22.02 & & & & \\
\hline & General & 21.81 & 21.74 & & & & & \\
\hline \multirow{5}{*}{ Breast } & PC & 26.06 & 26.59 & 26.33 & \multirow{5}{*}{ NS } & \multirow{5}{*}{ NS } & \multirow{5}{*}{ NS } & \multirow{5}{*}{3.92} \\
\hline & NC & 26.40 & 26.70 & 26.55 & & & & \\
\hline & $\mathrm{NC}+\mathrm{NB} 1$ & 26.66 & 26.83 & 26.75 & & & & \\
\hline & $\mathrm{NC}+\mathrm{NB} 2$ & 26.28 & 26.92 & 26.60 & & & & \\
\hline & General & 26.35 & 26.76 & & & & & \\
\hline
\end{tabular}

$\mathrm{PC}$, positive control; NC, negative control; NB1, natural betaine supplementation level 1; NB2, natural betaine supplementation level 2; ${ }^{*}<<0.05$; ${ }^{* *} \mathrm{p}<0.01$; NS, not significant; $C V$, coefficient of variation, \% 
Table 5 - Carcass, leg, breast, and wing+back drip loss (\%) of 45-d-old broilers reared under different environmental conditions and fed diets supplemented or not with betaine.

\begin{tabular}{|c|c|c|c|c|c|c|c|c|}
\hline \multirow{2}{*}{ Item } & \multirow{2}{*}{ Diet (D) } & \multicolumn{2}{|c|}{ Environment (E) } & \multirow{2}{*}{ General } & \multicolumn{3}{|c|}{ Probability } & \multirow{2}{*}{$C V$} \\
\hline & & Heat stress & Controlled & & D & A & $\mathrm{D} \times \mathrm{E}$ & \\
\hline \multirow{5}{*}{ Carcass } & PC & 1.578 & 2.520 & 2.084 & \multirow{5}{*}{ NS } & \multirow{5}{*}{ * } & \multirow{5}{*}{ NS } & \multirow{5}{*}{25.11} \\
\hline & NC & 2.077 & 2.348 & 2.240 & & & & \\
\hline & $\mathrm{NC}+\mathrm{NB} 1$ & 2.177 & 2.433 & 2.322 & & & & \\
\hline & $N C+N B 2$ & 1.980 & 1.986 & 1.983 & & & & \\
\hline & General & $1.939 b$ & $2.351 \mathrm{a}$ & & & & & \\
\hline \multirow{5}{*}{ Leg } & PC & 1.306 & 1.523 & 1.415 & \multirow{5}{*}{ NS } & \multirow{5}{*}{ NS } & \multirow{5}{*}{ NS } & \multirow{5}{*}{26.05} \\
\hline & NC & 1.100 & 1.463 & 1.282 & & & & \\
\hline & $\mathrm{NC}+\mathrm{NB} 1$ & 1.398 & 1.440 & 1.419 & & & & \\
\hline & $\mathrm{NC}+\mathrm{NB} 2$ & 1.275 & 1.246 & 1.261 & & & & \\
\hline & General & 1.270 & 1.418 & & & & & \\
\hline \multirow{5}{*}{ Breast } & PC & 1.366 Ba & $2.104 \mathrm{Aa}$ & 1.735 & \multirow{5}{*}{ NS } & \multirow{5}{*}{ NS } & \multirow{5}{*}{ * } & \multirow{5}{*}{22.45} \\
\hline & NC & $1.760 \mathrm{Aa}$ & $1.753 \mathrm{Aa}$ & 1.757 & & & & \\
\hline & $N C+N B 1$ & $1.956 \mathrm{Aa}$ & $1.747 \mathrm{Aa}$ & 1.852 & & & & \\
\hline & $N C+N B 2$ & $1.608 \mathrm{Aa}$ & $1.796 \mathrm{Aa}$ & 1.702 & & & & \\
\hline & General & 1.673 & 1.850 & & & & & \\
\hline
\end{tabular}

$\mathrm{PC}$, positive control; NC, negative control; NB1, natural betaine supplementation level 1; NB2, natural betaine supplementation level $2 ;{ }^{*} p<0.05$; ${ }^{* *} p<0.01 ; \mathrm{NS}$, not significant; $C V$, coefficient of variation, \%

Means followed by the small letters in the same row and capital letters in the same column are not significantly different by the test of Tukey at $5 \%$ probability level.

through several metabolic routes (Partridge, 2002). However, this mode of action was not detected in the present study.

Relative to carcass and parts drip loss (Table 5), better water retention was expected in carcasses and parts due to the possible osmoprotectant action of betaine, but this effect was not evidenced, possibly due to the high experimental variability obtained for drip loss, which may have affected the sensitivity of the mean comparison test.

Carcass drip loss was affected only by the environment, and broilers reared under cyclic heat stress presented lower drip loss. There was a significant interaction (diet vs. environment) for breast drip loss. When the interaction was broken down, no effect of the diet was detected, but birds fed the positive control diet presented higher drip loss when reared in the controlled environment than when submitted to cyclic heat stress. It was reported that betaine promoted higher water retention in broilers exposed to cyclic heat stress (Mooney et al., 1998).

The morphometrics of the duodenal crypts and villi of 45-d-old broilers are shown in Table 6 . The results do not show any influence of diet or environment on these parameters, nor any significant interaction between these factors.
Some studies indicate that betaine supplementation may be beneficial to the intestinal epithelium (Kettunen et al., 2001) due to its osmolyte function, maintaining villi integrity and consequently promoting better nutrient digestibility and absorption (Eklund et al., 2005).

Under challenge conditions, dietary betaine, due to its osmoprotectant action, helps to maintain the integrity of the intestinal epithelium, preventing disorders that may cause metabolic changes and reduce nutrient absorption. The most significant effects of betaine are reported when broilers are challenged by pathogens that affect villi, as shown by Klasing et al. (2002), who after seven days of inoculating broilers with Eimeira found that those fed $0.10 \%$ betaine presented higher villi.

In the present study, the only way to challenge the birds was not cleaning the drinkers every day. However, the results showed that the challenge was not sufficient to evidence any action of betaine on intestinal villi or crypt.

\section{CONCLUSIONS}

The addition of betaine in the diet, with $11.18 \%$ digestible methionine and $24.73 \%$ total choline reductions, did not affect broiler live performance, carcass yield, or intestinal morphology. 
Table 6 - Crypt depth $(\mathrm{CD}, \mathrm{mm})$ and villus height $(\mathrm{VH}, \mathrm{mm})$ in the jejunum of 45 -d-old broilers.

\begin{tabular}{|c|c|c|c|c|c|c|c|c|}
\hline \multirow{2}{*}{ Item } & \multirow{2}{*}{ Diet (D) } & \multicolumn{2}{|c|}{ Environment (E) } & \multirow{2}{*}{ General } & \multicolumn{3}{|c|}{ Probability } & \multirow{2}{*}{$\mathrm{CV}(\%)$} \\
\hline & & Heat stress & Controlled & & $\mathrm{D}$ & A & $D \times E$ & \\
\hline \multirow{5}{*}{$C D$} & PC & 0.317 & 0.323 & 0.320 & \multirow{5}{*}{ NS } & \multirow{5}{*}{ NS } & \multirow{5}{*}{ NS } & \multirow{5}{*}{17.23} \\
\hline & NC & 0.375 & 0.328 & 0.349 & & & & \\
\hline & $N C+N B 1$ & 0.332 & 0.368 & 0.347 & & & & \\
\hline & $\mathrm{NC}+\mathrm{NB} 2$ & 0.429 & 0.331 & 0.370 & & & & \\
\hline & General & 0.353 & 0.334 & & & & & \\
\hline \multirow{5}{*}{$\mathrm{VH}$} & PC & 1.156 & 1.227 & 1.192 & \multirow{5}{*}{ NS } & \multirow{5}{*}{ NS } & \multirow{5}{*}{ NS } & \multirow{5}{*}{17.87} \\
\hline & NC & 1.301 & 1.215 & 1.253 & & & & \\
\hline & $N C+N B 1$ & 1.349 & 1.404 & 1.372 & & & & \\
\hline & $N C+N B 2$ & 1.305 & 1.241 & 1.266 & & & & \\
\hline & General & 1.277 & 1.258 & & & & & \\
\hline
\end{tabular}

$\mathrm{PC}$, positive control; NC, negative control; NB1, natural betaine supplementation level 1; NB2, natural betaine supplementation level 2; ${ }^{*}<<0.05$; ${ }^{* *} p<0.01$; NS, not significant; $C V$, coefficient of variation, \%

\section{REFERENCES}

Augustine PC, Mcnaughton JL, Virtanen E, Rosi L. Effect of betaine on the growth performance of chicks inoculated with mixed cultures of avian Eimeria species and on invasion and development of Eimeriatenella and Eimeriaacervulina in vitro and in vivo, Poultry Science 1997;76(6):802809.

Behmer AO, Tolosa EMC, Freitas-Neto AG. Manual de técnicas para histologia e patológica. São Paulo: EUSPE; 1976.

Boch, J, Kempf B, Bremer E. Osmoregulation in Bacillus subtilis: Synthesis of the osmoprotectant glycine betaine from exogenously provided choline. Journal of Bacteriology 1997; 176 (17):5364-5371.

Bowmaker, JE, Gous RM. The response of broiler breeder hens to dietary lysine and methionine. British Poultry Science 1991;32(5):1069-1088.

Bridi AM, Nicolaiewsky S, Rübensam JM, Both MC, Lobato JFP.Efeito do genótipo halotano e de diferentes sistemas de produção na qualidade da carne suína. Revista Brasileira Zootecnia 2006;32(6):942-950.

Eklund M, Bauer E, Wamatu J, Mosenthin R. Potential nutritional and physiological functions of betaine in livestock. Nutrition Research Reviews 2005;18(1):31-48.

Hassan RA, Attia YA, El-Ganzory EH. Growth, carcass quality and serum constituents of slow growing chicks as affected by betaine addition to diets containing different levels of choline. International Journal of Poultry Science 2005;4(11):840-850.

Honarbakhsh SS, Zaghari M, Shivazad M. Can exogenous betaine be an effective osmolyte in broiler chicks under water salinity stress? AsianAustralasian Journal of Animal Sciences 2007;20(11):1729-1737.

Kettunen $\mathrm{H}$, Tiihonen K, Peuranen S, Saarinen MT, Remus JC. Dietary betaine accumulates in the liver and intestinal tissue and stabilizes the intestinal epithelial structure in healthy and coccidia-infected broiler chicks. Comparative Biochemistry and Physiology Part A: Molecular \& Integrative Physiology 2001;130(4):759-769.

Kidd MT, Ferket PR, Garlich JD. Nutritional and osmoregulatory functions of betaine.World's Poultry Science Journal 1997;53(2):125-139.

Klasing KC, Adler KL, Remus JC, Calvert CC. Dietary betaína increases intraepithelial lymphocytes in the duodenum of coccidian-infected chicks and increases functional properties of phagocytes. Journal of Nutrition 2002;132(8):2274-2282.
Mcdevitt RM, Mack S, Wallis IR. Can betaine partially replace or enhance the effect of methionine by improving broiler growth and carcase characteristics. British Poultry Science 2000;41(4):473-80.

Mooney M, Belay T, Teeter RG. Effect of betaine on loss of corporal water. In: Proceedings of the International Poultry Scientific Forum: Southern Poultry Science Society and Southern Conference on Avian Diseases, 1998, Atlanta, GA, Proceedings... Atlanta. 1998.

Paniz C, Grotto D, Schmitt GC, Valentini J, Schott KL, Pomblum VJ, Garcia SC, Fisiopatologia da deficiência de vitamina B12 e seu diagnóstico laboratorial. Jornal Brasileiro de Patologia e Medicina Laboratorial 2005;41(5)323-334.

Partridge G. Betainefromsugarbeetgivesanenergyboost. Piglnternational 2002;32(1): 21.

Pesti GM, Harper AE, Sunde ML. Sulfur amino acid and methyl donor status of corn-soy diets fed to starting broiler chicks and turkey poultry's. Poultry Science 1979;58(6):1541-1547.

Rasband WS. Imagej. Bethesda: National Institutes of Health; 2004. Available from: http.//rsb.info.nih.gov/ij/.

Rostagno HS, Pack M. Can Betaine Replace supplemental dl-methionine in broiler diets? Journal of Applied Poultry Research 1996;5(2):150-154.

Rostagno HS, Albino LFT, Donzele JL, Gomes PC, Oliveira RF, Lopes DC, et al. Tabelas brasileiras para aves e suínos: "Composição de alimentos e exigências nutricionais". Viçosa(MG): UFV Impensa Universitária; 2005.

Sakomura NK, Rostagno HS. Métodos de pesquisa em nutrição de monogástricos. Jaboticabal: Funep; 2007.

SAS Institute. SAS/STAT: user's guide, version $8^{\text {th }}$ ed. Cary, NC; 2001.

Schutte JB, DE Jong J, Smink W, Pack M. Replacement value of betaine for DL-methionine in male broiler chicks. Poultry Science 1997;76(2):321325. 